\title{
PENGARUH PEMBERIAN RUMPUT RAJA (Pennisetum purpupoides) DAN TEBON JAGUNG TERHADAP KECERNAAN BAHAN KERING DAN BAHAN ORGANIK PADA SAPI PO PEDET JANTAN
}

\author{
Nasriya, Ronny A.V. Tuturoong*, Ch. L. Kaunang, S.S. Malalantang, \\ M. M. Tindangan
}

Fakultas Peternakan Universitas Sam Ratulangi, Manado 95115

\begin{abstract}
ABSTRAK
Penelitian tentang pemberian rumput raja (Pennisetum purpupoides) dan tebon jagung sebagai pakan penyusun ransum telah dilaksanakan untuk mengetahui pengaruhnya terhadap kecernaan bahan kering dan kecernaan bahan organik pada sapi peranakan ongole (PO) pedet jantan. Penelitian ini menggunakan 5 ekor sapi PO pedet jantan dengan berat badan $\pm 100 \mathrm{~kg}$. Rancangan yang digunakan adalah Rancangan Bujur Sangkar Latin (RBSL) yang terdiri dari 5 perlakuan. Perlakuan tersebut adalah perbandingan antara rumput raja dan tebon jagung, yaitu $\mathrm{R} 1=100 \%$ rumput raja, $\mathrm{R} 2=$ $75 \%$ rumput raja $+25 \%$ tebon jagung, $\mathrm{R} 3=$ $50 \%$ rumput raja $+50 \%$ tebon jagung, $\mathrm{R} 4=$ $25 \%$ rumput raja $+75 \%$ tebon jagung dan $\mathrm{R} 5$ $=100 \%$ tebon jagung. Variabel yang diamati adalah kecernaan bahan kering dan kecernaan bahan organik. Hasil analisis keragaman menunjukkan bahwa perlakuan memberi pengaruh yang tidak nyata terhadap kecernaan bahan kering dan kecernaan bahan organik. Rataan kecernaan bahan kering sapi PO pedet jantan dalam penelitian ini berkisar antara 56,27\%-59,48\%. Angka kecernaan tertinggi terdapat pada R5 dengan pemberian pakan $100 \%$ tebon jagung tanpa rumput raja yaitu $59,48 \%$ dan terendah pada perlakuan R1 dengan pemberian $100 \%$ rumput raja tanpa tebon jagung yaitu 56,27\%. Rata-rata kecernaan bahan organik sapi PO pedet jantan dalam penelitian ini berkisar antara 87,64\%$88,72 \%$. Angka kecernaan bahan organik tertinggi terdapat pada perlakuan R4 dengan pemberian pakan $25 \%$ rumput raja dan $75 \%$ tebon jagung yaitu $88,72 \%$ dan terendah pada perlakuan R2 dengan pemberian pakan $75 \%$
\end{abstract}

*Korespondensi (corresponding author):

Email: ronny.tuturoong@yahoo.com rumput raja dan $25 \%$ tebon jagung yaitu sebesar $87,64 \%$ g. Pengaruh pemberian rumput raja dan tebon jagung terhadap kecernaan bahan kering dan kecernaan bahan organik pada sapi PO pedet jantan memberikan nilai nutrisi terbaik pada kombinasi R4 25\% rumput raja dan $75 \%$ tebon jagung.

Kata kunci: Rumput Raja, Tebon Jagung, Kecernaan, Bahan Kering, Bahan Organik

\begin{abstract}
THE EFFECTS OF OFFERING KING GRASS (Pennisetum purpupoides) AND CORN STOVER ON DRY MATTER AND ORGANIC MATTER OF ONGOLE CROSS BREED STEER CALVES. A research has been conducted to evaluate the effects of offering king grass (Pennisetum purpupoides) and corn stover as ingredients for ration formulating on dry matter and organic matter digestibility of ongole cross breed steer calves. Five ongole cross breed steer calves with about $100 \mathrm{~kg}$ body weight were used in this experiment. Latin square design with 5 tereatments was used. The treatments were rasio of king grass and corn stover; $\mathrm{R} 1=100 \%$ king grass, $\mathrm{R} 2=$ $75 \%$ king grass $+25 \%$ corn stover, $\mathrm{R} 3=50 \%$ king grass $+50 \%$ corn stover, $\mathrm{R} 4=25 \%$ king grass $+75 \%$ corn stover, R5 $100 \%$ corn stover. The variables measured were dry matter and organic matter digestibility.
\end{abstract}


Analysis of variance showed that there were no significant effect of treatments on dry metter and organic matter digestibility. Averages of dry matter digestibility during experiment ranged $56.27 \%-59.48 \%$. The highest was $59.48 \%$ for R5 $(100 \%$ corn stover) and the lowest was $56.27 \%$ for R1 (100\% king grass). Averages of organic matter ranged from $87.64 \%$ to $88.72 \%$. The highest organic matter digestibility was on R4 ( $25 \%$ king grass $+75 \%$ corn stover) and the lowest organic matter digestibility was on R2 ( $75 \%$ king grass $+25 \%$ corn stover). It can be concluded that the best nutritive value was at combination of $25 \%$ king grass $+75 \%$ corn stover on dry matter and organic matter digestibility of ongole cross breed steer calves.

keywords: king grass, corn stover, digestibility, dry matter, organic matter

\section{PENDAHULUAN}

Sumber pakan utama ternak ruminansia di Indonesia adalah hijauan pakan dan limbah pertanian. Rumput Raja (Pennisetum purpoides) dan tebon jagung merupakan sumber pakan lokal yang potensial dan dimanfaatkan oleh peternak. Produksi rumput raja cukup tinggi, yaitu 200-250 ton/hektar/tahun (Rukman, 2005) dengan kandungan nutrisi BK 21,21\%, TDN 53,89\% (Wahyuni, 2007) SK 25,48\%, PK 11,68\%, Ca 0,37\% dan P 0,39\% (Rumiyati, 2008). Tebon jagung adalah seluruh tanaman jagung termasuk batang, daun dan buah jagung muda yang umumnya dipanen pada umur tanaman 45-65 hari (Soeharsono dan Sudaryanto,
2006) dengan kandungan nutrisi tebon jagung yaitu, PK 12,06\%, SK 25,2\%, Ca 0,28\%, P 0,23\% (Erna dan Sarjiman).

Nilai manfaat suatu bahan pakan dapat diketahui melalui percobaan kecernaan pada ternak. Kecernaan bahan pakan dipengaruhi oleh beberapa faktor antara lain komposisi kimia bahan pakan, jumlah pakan yang dikonsumsi ternak, frekuensi pemberian pakan, bentuk fisik pakan, jenis pakan, umur tanaman, temperatur lingkungan, spesies, umur ternak, keragaman antara individu ternak dan aktivitas mikroba. Penentuan kecernaan bahan pakan pada ternak ruminansia dapat dilakukan melalui beberapa metode, yaitu penentuan secara in vitro, in sacco dan in vivo. Kecernaan in vivo mengukur kecernaan pada ternak dengan melihat selisi antara konsumsi dan feses dengan pemahaman bahwa apa yang dikeluarkan oleh ternak melalui feses tidak dicerna. Pencernaan ruminansia terjadi secara mekanis, fermentatif dan hidrolisis (Mc Donald et al., 2002). Dengan metode in vivo dapat diketahui pencernaan bahan pakan yang terjadi di dalam saluran pencernaan ternak, sehingga nilai kecernaan pakan yang diperoleh mendekati nilai sebenarnya (Tilman et al., 1991)

Berdasarkan hal tersebut maka telah dilaksanakan penelitian yang bertujuan untuk mengevaluasi rumput raja 
dan tebon jagung terhadap kecernaan bahan kering dan kecernaan bahan organik pada sapi PO pedet jantan.

\section{MATERI DAN METODE PENELITIAN}

\section{Materi Penelitan}

Penelitian ini dilaksanakan di Balai Pembibitan Ternak Dinas Pertanian dan Peternakan Provinsi Sulawesi Utara. Desa Tampusu Kecamatan Romboken dari tanggal 24 Mei sampai dengan tanggal 29 juli 2015 .

Ternak yang digunakan dalam penelitian ini adalah sapi PO pedet jantan dengan berat badan $\pm 100 \mathrm{~kg}$. Kandang yang digunakan adalah kandang individual sebanyak 5 kandang yang dilengkapi dengan tempat makan dan minum. Peralatan lain yang digunakan yaitu kantong plastik kecil dan timbangan Ohaus untuk menimbang feses ternak serta skep mini untuk proses mengangkat feses.

Pakan yang digunakan adalah rumput raja pada umur pemotongan 60 hari. Tebon jagung merupakan jagung muda umur 60-70 hari termasuk batang daun bunga dan buah. Cara pengolahan tebon jagung yaitu tebon jagung dicacah (chopper) dengan panjang $5 \mathrm{~cm}$ dan langsung diberikan pada ternak, dengan penambahan dedak padi sebanyak 1 kg/ekor/hari.

Komposisi zat makanan dari rumput raja dan tebon jagung yang digunakan serta formulasi pakan penelitian dapat dilihat pada Tabel 1 dan Tabel 2.

\section{Metode Penelitian}

Penelitian ini dirancang dengan mengunakan Rancangan Bujur Sangkar Latin (RBSL) yang terdiri dari 5 perlakuan. Respon sapi PO pedet jantan terhadap penggunaan rumput raja dan tebon jagung diukur melalui:

1. Kecernaan bahan kering diperoleh dari selisih antara jumlah konsumsi bahan kering kurang bahan kering feses per konsumsi bahan kering dikali seratus persen

2. Kecernaan bahan oranik diperoleh dari selisih antara konsumsi bahan organik kurang bahan organik feses per konsumsi bahan organik dikali seratus persen.

\section{Tatalaksana Penelitian}

Penelitian ini dilaksanakan dalam tiga tahap, yaitu :

1. Tahap pendahuluan

Pada awal penelitian ternak diberikan kesempatan untuk beradaptasi dengan pakan perlakuan. 
Tabel 1. Komposisi Zat-Zat Makanan Bahan Pakan Penelitian

\begin{tabular}{lcc}
\hline \multicolumn{1}{c}{ Zat - zat makanan } & \multicolumn{2}{c}{ Bahan Pakan } \\
\cline { 2 - 3 } & $22^{*}$ & Tebon jagung** \\
\hline Bahan Kering & $79.41^{*}$ & $32^{*}$ \\
Bahan Organik & $11,68^{* *}$ & $82.64^{*}$ \\
Protein Kasar (\%) & $25,48^{* *}$ & $12.06^{* * *}$ \\
Serat Kasar (\%) & $2070^{* *}$ & $25,2^{* * *}$ \\
Energi Metabolisme (kkal/kg) & $2350^{* * *}$ \\
\hline Keterangan:*) Hasil Analisis Laboraturium Nutrisi dan Makanan Ternak Fakultas Peternakan \\
$\quad$ Universitas Sam Ratulangi Manado 2015 \\
**) Rumiyati , 2008 \\
* $^{* *)}$ Erna dan Sarjiman, 2007
\end{tabular}

Tabel 2. Formulasi Pakan Perlakuan dan Komposisi Zat-Zat Makanan

\begin{tabular}{lccccc}
\hline \multicolumn{1}{c}{ Bahan Pakan } & \multicolumn{5}{c}{ Perlakuan } \\
\cline { 2 - 6 } & $\mathrm{R} 1$ & $\mathrm{R} 2$ & $\mathrm{R} 3$ & $\mathrm{R} 4$ & $\mathrm{R} 5$ \\
\hline Rumput Raja & 100 & 75 & 50 & 25 & 0 \\
Hijauan Jagung & 0 & 25 & 50 & 75 & 100 \\
Total & 100 & 100 & 100 & 100 & 100 \\
Komposisi Zat Makanan (\%) & & & & & \\
Bahan Kering & 22 & 24.5 & 27 & 29.5 & 32 \\
Bahan Organik & 79.41 & 82.22 & 81.02 & 81.83 & 82.84 \\
Protein Kasar & 11.68 & 11.77 & 11.88 & 11.96 & 12.06 \\
Serat Kasar & 25.48 & 25.41 & 25.34 & 25.27 & 25.02 \\
Energi Metabolisme (kkal/kg) & 2070 & 2140 & 2210 & 2280 & 2350 \\
\hline
\end{tabular}

Keterangan: Komposisi zat makanan dihitung berdasarkan Tabel 1

Adaptasi pakan dilakukan selama 4 hari. Adaptasi dilakukan dengan tujuan untuk membiasakan ternak mengkonsumsi pakan perlakuan dan mengetahui konsumsi pakan. Konsumsi ternak dihitung dari kemampuan ternak mengkonsumsi pakan perlakuan yang dihitung berdasarkan konsumsi bahan kering. Pada masa adaptasi ini ternak diberikan obat cacing wormectin untuk mencegah pengaruh cacing dan parasit.

2. Tahap pra-koleksi
Tiga hari sebelum pengambilan data koleksi, dilakukan pembatasan pemberian pakan sebanyak $85 \%$ dari rataan konsumsi pakan pada tahap pendahuluan. Pembatasan pakan dilakukan agar pakan yang diberikan dapat dikonsumsi secara keseluruhan dan tidak tersisa.

3. Tahap koleksi

Pada tahap ini, pakan tetap diberikan sebanyak $85 \%$. Feses ditimbang setiap defikasi dan diambil sampel $10 \%$ untuk analisis. 
Pengumpulan feses dilakukan selama 5 hari begitu juga dengan pengambilan sampel pakan. Pada periode ini pakan diambil sebanyak 200 gr setiap hari.

\section{HASIL DAN PEMBAHASAN}

Data hasil penelitian tentang pemberian rumput raja (Pennisetum purpupoides) dan tebon jagung terhadap kecernaan bahan kering dan bahan organik pada sapi PO pedet jantan dapat dilihat pada Tabel 3.

\section{Kecernaan Bahan Kering}

Rataan Kecernaan bahan kering sapi PO pedet jantan dalam penelitian berkisar antara 56,27\% - 59,48\%. Angka kecernaan tertinggi terdapat pada R5 dengan pemberian pakan $100 \%$ tebon jagung tanpa rumput raja yaitu 59,48\% dan terendah pada perlakuan R1 dengan pemberian $100 \%$ rumput raja dan $0 \%$ tebon jagung yaitu $56,27 \%$.
Analisis sidik ragam pengaruh pemberian rumput raja dan tebon jagung terhadap kecernaan bahan kering pada sapi PO pedet jantan tidak memperlihatkan pengaruh yang nyata $(\mathrm{P}>0,05)$. Menurut Suardin et al. (2014) bahwa faktor yang mempengaruhi terhadap kecernaan ditinjau dari segi pakan kecernaan dipengaruhi oleh perlakuan terhadap pakan (pengolahan, penyimpanan dan cara pemberian) jenis, jumlah dan komposisi pakan yang diberikan pada ternak. Hal ini juga diperkuat oleh Anggorodi (1994) bahwa faktor yang mempengaruhi nilai kecernaan bahan kering ransum adalah tingkat proporsi bahan pakan dalam ransum.

Peningkatan nilai kecernaan dikarenakan peningkatan proporsi kandungan tebon jagung dalam pakan percobaan. Data pada Tabel 2 menunjukan bahnwa terdapat penurunan protein kasar dan serat kasar sedangkan kandungan energi metabolik meningkat. Hal ini menjelaskan bahwa tebon jagung

Tabel 3. Rerata Kecernaan Bahan Kering (BK) dan Bahan Organik (BO) yang diberi Pakan Perlakuan Rumput Raja dan Tebon Jagung (\%/ekor/hari).

\begin{tabular}{lccccc}
\hline Parameter & \multicolumn{5}{c}{ Perlakuan } \\
\cline { 2 - 6 } & R1 & R2 & R3 & R4 & R5 \\
\hline Kecernaan BK & 56,27 & 57,38 & 57,52 & 58,01 & 59,48 \\
Kecernaan BO & 87,85 & 87,64 & 88,50 & 88,72 & 88,71 \\
\hline
\end{tabular}


memiliki BETN sebagai sumber energi yang terkandung dalam butiran jagung dan isi sel hijauan jagung. Sumber energi ini tergolong energi mudah tercerna readily available carbohydrat (RAC) yang dibutuhkan sebagai kerangkan karbon untuk pertumbuhan mikroba yang maksimal, semakin banyak RAC tersedia dalam pakan laju pertumbuhan mikroba akan meningkat dengan demikian kecernaan bahan kering meningkat.

Kecernan bahan kering pada penelitian ini lebih rendah dari yang dilakukan oleh Crhisterra dan Suharyanto (2013) yaitu sebesar 64,56\%-68,29\% yang menggunakan limbah tanaman jagung dengan penambahan biosuplemen, dan hampir sama dengan Erpomen et al. (2011) yang menggunakan silase jerami jagung muda, yaitu sebesar 53,32\%$59,29 \%$, dan lebih rendah dengan yang dilakukan Mayasari et al. (2015) yaitu sebesar 62,43\%-69,00\% dengan menggunakan jerami jagung yang ditambahkan nitrogen dan sulfur.

\section{Kecernaan Bahan Organik}

Rata-rata kecernaan bahan organik sapi PO pedet jantan dalam penelitian berkisar antara 87,64\% - 88,72\%. Angka kecernaan bahan organik tertinggi terdapat pada perlakuan R4 dengan pemberian pakan $75 \%$ tebon jagung dan $25 \%$ rumput raja yaitu $59,48 \%$ dan terendah pada perlakuan R2 dengan pemberian $75 \%$ rumput raja dan $25 \%$ tebon jagung yaitu $56,27 \%$.

Hasil analisis keragaman menunjukan bahwa pengunaan tebon jagung sampai level 100\% memberikan pengaruh yang sama $(\mathrm{P}>0,05)$ terhadap kecernaan bahan organik sapi PO pedet jantan. Adanya kecendurungan kenaikan bahan organik dikarenakan komposisi konsumsi tebon jagung yang meningkat diiringi dengan peningkatan energi yang berasal dari biji jagung dan inti sel hijauan jagung. Menurut Sutardi (1981) bahwa peningkatan energi yang berasal dari karbohidrat mudah tercerna akan meningkatkan sintesa mikroba rumen sehingga pada gilirannya dapat meningkatkan kecernaan bahan organik.

Kecernaan bahan organik pada penelitian ini lebih tinggi dari penelitian yang pernah dilakukan oleh Christlyanto et al. (2005) sebesar $72,23 \%$ - 74,74\% yang menggunakan pakan basal rumput raja, dan hampir sama dengan hasil penelitian yang dilakukan oleh Semaun (2011) yaitu KCBO sebesar 88,86\% - 89,34\% yang menggunakan jerami jagung dengan penambahan Aspergillus niger serta lebih tinggi dari hasil penelitian yang dilakukan oleh Amin (2010) yaitu sebesar 65,87\% $81,17 \%$ yang menggunakan jerami jagung dengan manure dan jerami kacang tanah. 
Kenaikan kecernaan bahan kering dan bahan organik pada penelitian ini dikarenakan meningkatnya kandungan protein pakan perlakuan. Pada rumen protein akan dihidrolisis oleh mikroba menjadi asam-asam amino. Asam-asam amino akan dirombak menjadi ammonia. Kurang lebih $82 \%$ mikroba rumen dapat menggunakan ammonia untuk perkembangannya (Arora, 1989). Makin tinggi perkembangan mikroba maka aktivitas mikroba dalam mencerna pakan juga semakin tinggi. McDonald et al. (1995) menyatakan bahwa apabila pakan rendah kandungan protein maka konsentrasi ammonia rumen akan rendah dan pertumbuhan mikroba rumen lambat, akibatnya degradasi karbohidrat akan terhambat.

\section{KESIMPULAN}

Pemberian rumput raja dan tebon jagung memberikan pengaruh yang sama terhadap kecernaan bahan kering dan bahan organik pada sapi PO pedet jantan.

\section{DAFTAR PUSTAKA}

Anggorodi, R. 1994. Ilmu Makanan Ternak Umum. PT.Gramedia Pustaka Utama. Jakarta

Amin, Nurul. 2010. Produktivitas Sapi Bali yang diberi pakan fermentasi jerami jagung dengan manure dan jerami kacang tanah. Jurnal Galung Tropika 3(1): 22-28. Diakses pada Tgl 10 April 2016.

Arora, S.P. 1989. Pencernaan Mikrobia Pada Ruminansia. Terjemahan: Retno Murwani. Gadjah Mada University Press. Yogyakarta

Christlyanto, M., R. Utomo, M. Soejono, H. Hartadi, dan B.P. Widyobroto. 2005. Konsumsi dan kecernaan nutrient ransum yang berbeda perekusor protein-energi dengan pakan basal rumput raja pada sapi perah. J. Indo. Trop. Anim. Agric. 30(4):242-247. Diakses Pada Tgl 9 April 2016

Crhisterra, E. dan W.T. Suharyanto. 2013. Pengaruh penggunaan pakan komplit berbasis limbah tanaman jagung dan sorgum pada produkvitas ternak domba. Seminar Nasional Teknologi Peternakan dan Veteriner. Hal: 356362. Diakses Pada Tgl 3 April 2016.

Erna, W dan Sarjiman, 2007. Budidaya hijauan pakan bersama tanaman pangan sebagai upaya penyediaan hijauan pakan di lahan sempit. Jurnal Peternakan dan Lingkungan. Vol 7: 134-141

Erpomen, M.A., A. Mawardi, R.W. Setia Ningrat. 2011. Kajian Nutrisi dan Optimalisasi Proses Pengolahan Silase Jagung Muda Sebagai Pakan Ternak Ruminansia. Laporan Penelitian. Fakultas Peternakan. Universitas Andalas. Diakses Pada Tgl 6 April 2016.

Mayasari, E., B. Ayuningsi, dan R. Hidayat. 2015. Pengaruh Penambahan Nitrogen dan Sulfur Pada Ensilase Jerami Jagung Terhadap Kecernaan Bahan Kering dan Bahan Organik Pada Sapi Potong. Laporan Penelitian. 
Fakultas Peternakan Universitas Padjadjaran. Diakses pada Tgl 8 April 2016

McDonald, P., R. Edwards, J. Greenhalgh, and C. Morgan. 2002. Animal Nutrition. 6th Edition. Longman Scientific \& Technical, New York.

Rukman. 2005. Budidaya Rumput Unggul. Kanisius. Yogyakarta.

Rumiyati. 2008. Pengaruh imbangan jerami kacang tanah dengan rumput raja dalam ransum terhadap performan sapi pfh jantan. Jurnal penelitian Ilmu Peternakan. Fakultas Pertanian Universitas Sebelas Maret Surakarta. Vol 9 : 62-68

Semaun, Rahmawati. 2011. Evaluasi Nilai Nutrisi dan Kecernaan Kombinasi Fermentasi Jerami Jagung Dengan Penambahan Aspergillus niger Dalam Ransum Sapi Bali. Skripsi. Program Studi Sistem-Sistem Pertanian Program Pascassarjana.Universitas Hasanudin Makasar. Diakses pada Tgl 10 April 2016

Soeharsono dan B. Sudaryanto. 2006. Tebon jagung sebagai sumber hijauan pakan ternak strategis di lahan kering kabupaten gunung kidul. Prosiding.
Lokakarya Nasional Jejaring Pengembangan Sistem Integrasi Jagung Sapi. Puslitbang Peternakan, Bogor. hlm. $136-141$.

Suardin, N. Sadiah dan R. Aka. 2014. Kecernaan bahan kering dan bahan organik campuran campuran rumput mulato (brachiria hybrid.cv mulato) dengan jenis legum berbeda menggunakan cairan rumen sapi. Jitro Vol 1(1): 16-22.

Sutardi, T. 1981. Sapi Perah dan Pembagian Makanannya. Depertemen Ilmu Makanan Ternak. Fakultas Peternakan IPB. Bogor

Tilman, A.D., H. Hartadi, S. Reksohadiprodjo, S. Prawirokusumo, dan S. Lebdosoekojo. 1991. Ilmu Makanan Ternak Dasar. Gadjah Mada University Press. Yogyakarta

Wahyuni, S. 2007. Pengaruh Penggunaan Campuran Ampas Bird dan Onggok Dalam Konsentrat Terhadap Kecernaan Bahan Kering dan Bahan Oragnik Domba Lokal Jantan. Skripsi. Program Studi Peternakan. Fakultas Pertanian Universitas Sebelas Maret Surakarta. 